\title{
ANTIOXIDANT PROPERTY OF Solanum nigrum AGAINST HEAVY METAL CHROMIUM PADMAKSHI SINGH ${ }^{1}$
}

\author{
Department of Chemistry, T.D. P.G. College, Jaunpur, Uttar Pradesh, India
}

\begin{abstract}
In environment there are varied form of life. Depending on its physical, chemical and biological properties, heavy metals have been released into the environment may move within an aquifer in the same manner that ground water contaminants. The contamination of nature compartments by heavy metals has become a serious environmental problem. Due to high cost of conventional cleanup technology, there is an increasing interest in the remediation of contaminated sites using biological environmental friendly technique i.e. phytoremediation. It this technique in which soil contamination due to industrial activities is minimized. In this method heavy metals are isolated and detoxify. Phytoremediation process is widely accepted as a cost effective and environmental friendly cleanup technology. During the exposure of plants to contaminated soils the antioxidant defense system helps the plant to protect itself from the damage. Antioxidants are substances used the body to protect itself from damage caused by oxidation due to toxic environment. Solanum nigrum (Black night shade) is common plant grown in all part of the India. In the presence work the plant $S$. nigrum was exposed to the heavy metal chromium contaminated soils and the biological factors, vitamins and mineral factor and antioxidant factors were investigated. From the observation it is evident that the heavy metal chromium affects significantly the biochemical factors, vitamins and mineral factors and antioxidant factors in $\mathbf{S}$. nigrum plant. It is also clear that Solanum nigrum is found to be heavy higher antioxidant property than other plants.
\end{abstract}

KEYWORDS: Solanum nigrum, Phytoremediation, Antioxidant Factors

Industrial development and urbanization have resulted several environmental problems in India. Organic and inorganic pollutants including coloured substances, heavy metals, sewage, fertilizers and pesticides increase concentration heavy metal including chromium in soil (Angelone and Bini, 1992). The presence of these contaminants changes physical, chemical and biological status of soil. Some medicinal plants such as Solanum nigrum, Helianthus annus, Annula racemosa Solanum xanthcorpum etc. minimise the concentration of these pollutants and enhance biological property of soil (Bergmann and Rennenberg, 1993). The black nightshades (Solanum nigrum L. and related species) are worldwide weeds of arable land, gardens, rubbish tips, soils rich in nitrogen, in moderately light and' warm situations which occur from sea to mountane levels. They are, however, also widely used as leafy herbs and vegetables, as a source of fruit and for various medicinal purposes.

Solanum nigrum was exposed to the metal Chromium contaminated soils and the biochemical factors, vitamins and minerals factors and antioxidant factors were tested. The present efficiency of soil indicate removal of heavy metals with chromium and show antioxidant property (Berti and Cunningham, 2000) (Blaylock and Huang, 2000).

\section{MATERIALS AND METHODS}

\section{Preparation of Polluted Soil}

Top soil upto $15 \mathrm{cms}$ depth, was collected from the fertile agriclutrual lands of Bhualpur village near Chunar Mirzapur (U.P.). The samples were air dried, crushed to powder and sieved in $0.5 \mathrm{~mm}$ mesh. The sieved soil samples were stored in polythene bags.

Different concentrations of Sodium dichromate were mixed with 600 gms of the soil samples and the samplings of the Solanum nigrum plants was planted to different pots. The toxicity of the cadmium metal on the both the plants was investigated after a time period of three weeks.

The sublethal concentration and half of sublethal concentration of the Sodium dichromate solution were selected for the toxicity studies of the chromium on the Solanum nigrum plants. The plants were exposed to the above metal contaminated soils for four weeks and the biochemical factors, vitamins and minerals factors and antioxidant factors were tested as per standard methods. Carbohydrates, protein, amino acids, fatty acids, DPPH were analyse by following methods:

1. Determination of total carbohydrates by Anthrone method

2. Protein estimation by Lowry's method (Blois, 1958) 
3. Estimation of protein, total free amino acids, proline, reduced glutathione, superoxide dismutase and catalase are done by colorimetric method

4. Estimation of free fatty acids (Titration)

5. DPPH free radical scavenging activity (Blois method) (Chaoui et al., 1997)

\section{RESULTS AND DISCUSSION}

In the present research work an attempt has been made to study the effect of Chromium metal polluted soils on the various antioxidant factors, vitamins and minerals factors and biochemical properties of the plants Solanum nigrum. In table 1 presents the Biochemical factors of the plant Solanum nigrum grown in fertile garden soil, sublethal and half of sublethal Chromium polluted soil (Clemens et al., 2002). The total carbohydrates, total proteins, fats, chlorophyll, Total amino acid and the amino acid except proline were considerably reduced in the plants sample of Solanum nigrum exposed to heavy metal Chromium contaminated soil (Cobbett, 2000).

Table 1: Biochemical Factors of the plant Solanum nigrum

\begin{tabular}{|c|c|c|c|}
\hline \multirow{2}{*}{ Factors } & \multicolumn{3}{|c|}{ Solanum nigrum } \\
\cline { 2 - 4 } & Control & Sublethal Cr & Half of sublethal Cr \\
\hline CHO g/100g & 7.5 & 5.2 & 6.9 \\
\hline Protein $\mathrm{g} / 100 \mathrm{~g}$ & 7.6 & 5.41 & 6.50 \\
\hline Fat $\mathrm{g} / 100 \mathrm{~g}$ & 0.8 & 0.70 & 0.75 \\
\hline Chlorophyll $\mu \mathrm{g} / 100 \mathrm{~g}$ & 20.8 & 15.4 & 17.1 \\
\hline Total amino acid g/100g & 4.2 & 3.34 & 3.52 \\
\hline Proline $\mathrm{g} / 100 \mathrm{~g}$ & 4.7 & 6.12 & 4.15 \\
\hline
\end{tabular}

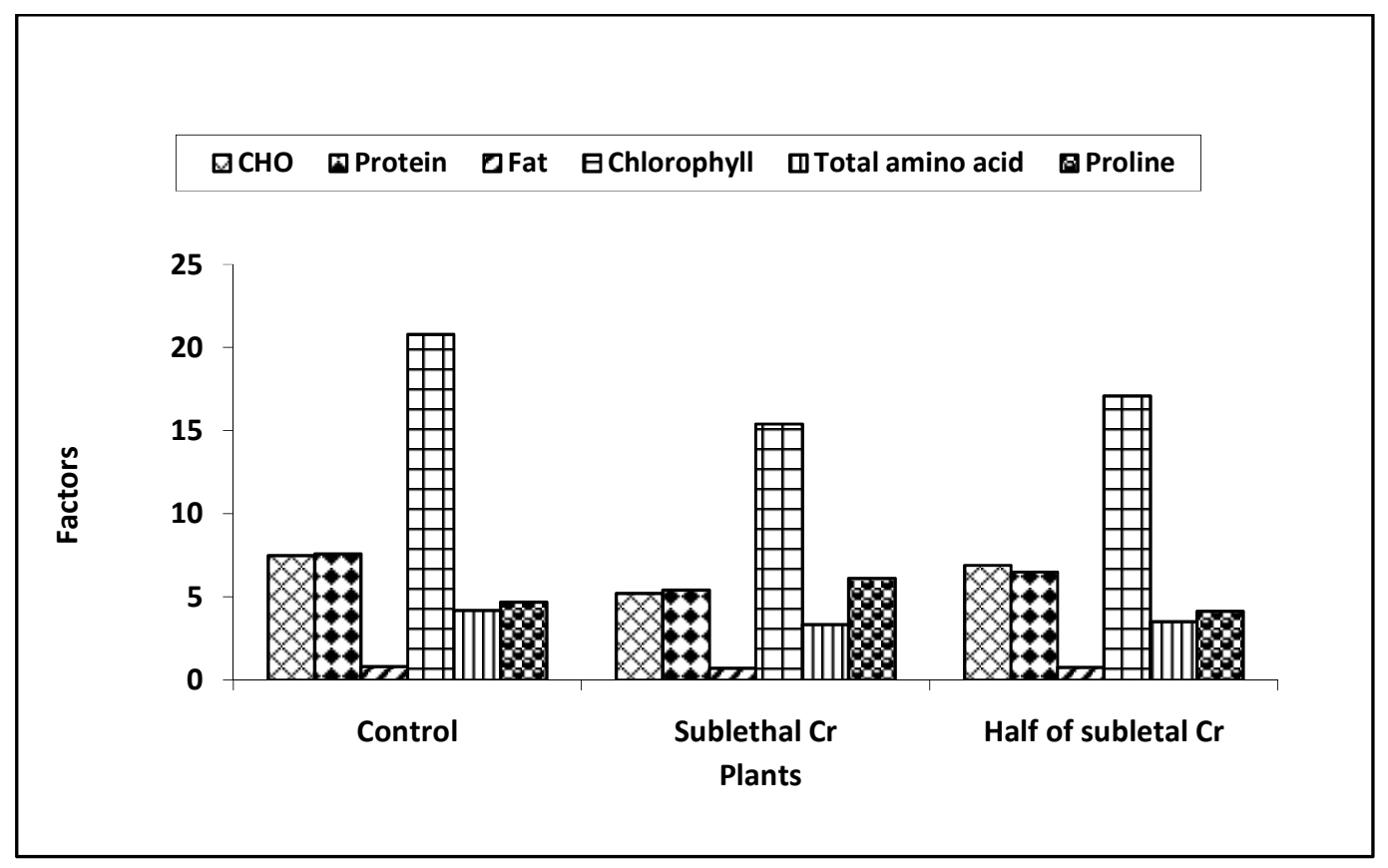

Figure 1: Biochemical factors of the plant Solonum nigrum

This may be because proline a non essential amino acid is synthesized in the living organism whenever it is subjected to stress such as high or low temperatures, high salinity, sodicity, high heavy metal exposures etc. Proline accumulation is a common metabolic response of higher plants to water deficits, and salinity stress, and has been the subject of numerous reviews over the last 20 years (Gerard et al., 2000). Proline protects membranes and proteins against the adverse effects of high concentrations of inorganic ions and temperature extremes. Proline may also function as a protein-compatible hydrotrope and as hydroxyl radical 
scavenger (Godbold and Hittermann, 1985). Proline is organic amino acid, that is used in the biosynthesis of proteins and contain $\alpha$-amino amino group.

Table 2 shows the vitamin and mineral content of the plants Solanum nigrum grown in fertile garden soil, sublethal and half of sublethal Chromium polluted soil.
The factors were reduced significantly in the heavy metal contaminated soil (Kramer and Chardonnens, 2001). The vitamins $\mathrm{A}, \mathrm{B}$ and $\mathrm{C}$ and total phenolics and other minerals were significantly high in the normal plant showing that the plant is rich in antioxidant phytochemicals.

Table 2: Vitamins and Minerals Factors of the plant Solanum nigrum

\begin{tabular}{|c|c|c|c|}
\hline \multirow{2}{*}{ Factors } & \multicolumn{3}{|c|}{ Solanum nigrum } \\
\cline { 2 - 4 } & Control & Sublethal Cr & Half of sublethal Cr \\
\hline Total Phenolics $\mathrm{mg} / 100 \mathrm{~g}$ & 900 & 597.1 & 710.6 \\
\hline$\beta$-Carotene $\mu \mathrm{g} / 100 \mathrm{~g}$ & 44.0 & 37.9 & 41.0 \\
\hline Ascorbic acid $\mu / 100 \mathrm{~g}$ & 490 & 379 & 461 \\
\hline Thiamine $\mu / 100 \mathrm{~g}$ & 0.15 & 0.13 & 0.14 \\
\hline Total Ash $\mathrm{g} / 100 \mathrm{~g}$ & 3.1 & 2.10 & 2.95 \\
\hline $\mathrm{K} \mathrm{mg} / 100 \mathrm{~g}$ & 415 & 322.5 & 366.0 \\
\hline $\mathrm{Na} \mathrm{mg/100g}$ & 34 & 27.6 & 41.4 \\
\hline Fe $\mathrm{mg} / 100 \mathrm{~g}$ & 53 & 31.9 & 417 \\
\hline $\mathrm{Ca} \mathrm{mg} / 100 \mathrm{~g}$ & 434 & 316 & 417 \\
\hline
\end{tabular}

Table 3 shows the antioxidant enzyme levels and the percentage antioxidant activity of the plants Solanum nigrum plant. The antioxidant activity was found to be the maximum when the plants exposed to control soil (Koppolua et al., 2003). The same has been reduced much in the plants exposed to sublethal Chromium and half of sub lethal Chromium exposed soil. This shows that the free radical scavenging activity is reduced much in the plant exposed to heavy metal contaminated soils (Lowry et al., 1951). The enzymes Superoxide dismutase, catalase and glutathione were increased significantly in the plant sample exposed to heavy metal contaminated soils (Mehra and Tripathi, 1999).

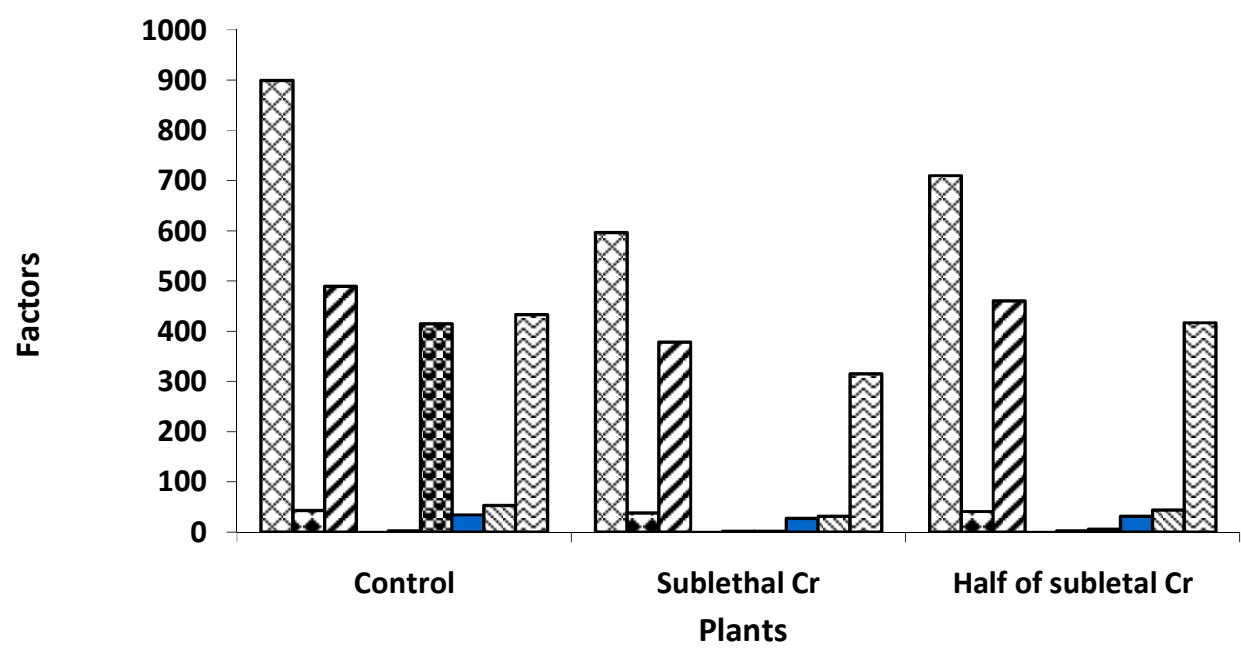

Figure 2: Vitamins and Minerals factors of the plant Solanum nigrum 
SINGH: ANTIOXIDANT PROPERTY OF Solanum nigrum AGAINST HEAVY METAL CHROMIUM

Table 3: Antioxidant properties of the plant Solanum nigrum

\begin{tabular}{|c|c|c|c|}
\hline \multirow{2}{*}{ Factors } & \multicolumn{3}{|c|}{ Solanum nigrum } \\
\cline { 2 - 4 } & Control & Sublethal Cr & Half of sublethal Cr \\
\hline AOA \% & 110 & 62 & 73 \\
\hline SOD $\mu \mathrm{gm} / \mathrm{minute} / \mathrm{mg}$ protein & 510 & 634 & 731 \\
\hline $\mathrm{GSH} \mathrm{mg} / \mathrm{g}$ & 16.4 & 17.6 & 19.5 \\
\hline Catalase $\mu / \mathrm{mol} / \mathrm{min} / \mathrm{g}$ & 7.54 & 7.59 & 6.85 \\
\hline
\end{tabular}

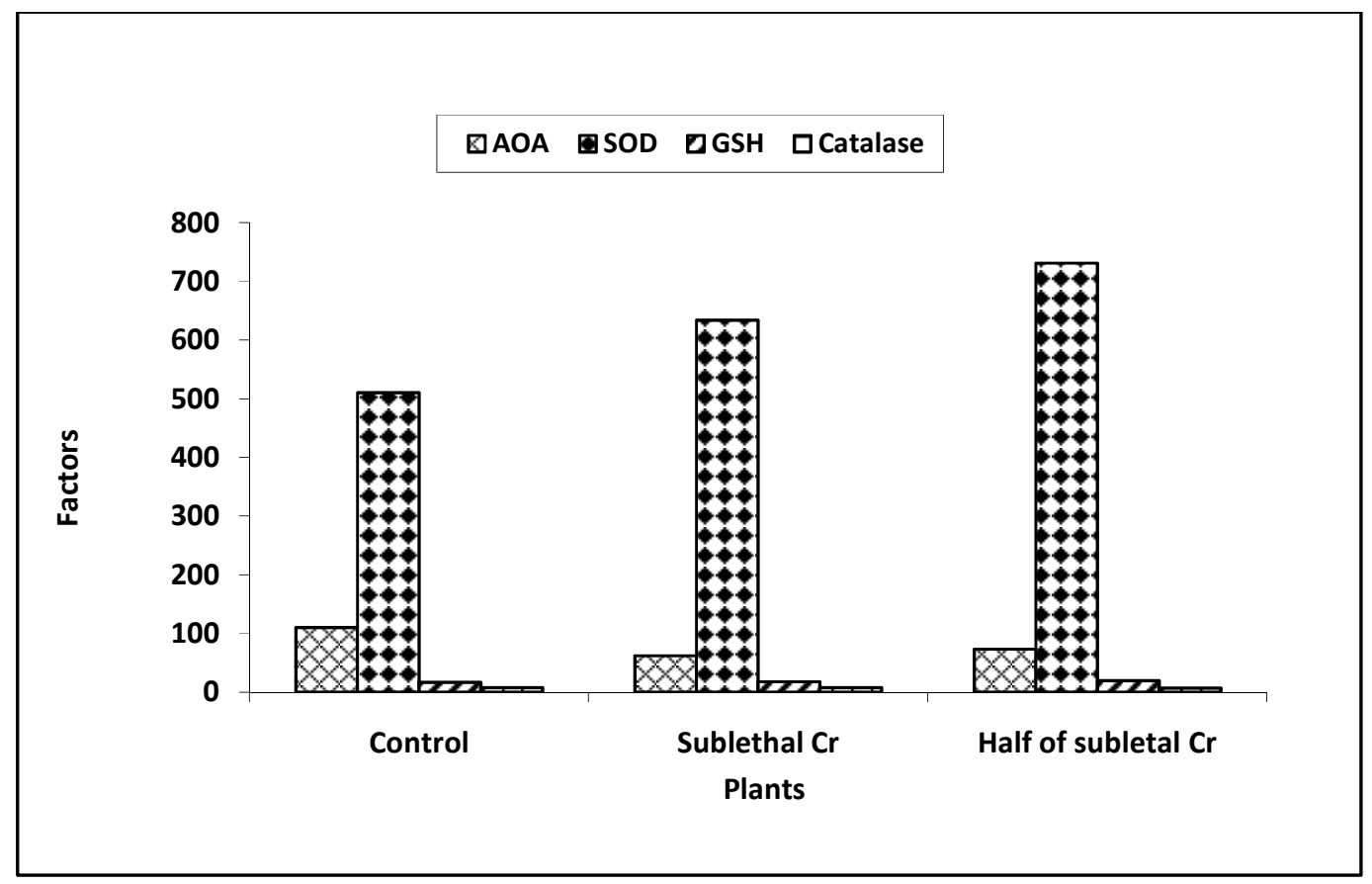

Figure 3: Antioxidant properties of the plant Solanum nigrum

Though some heavy metals are essential as micronutrients, uptake of higher concentrations of heavy metal is found to be toxic for plants (Rao and Sresty, 2000). Certain metals are known to produce/act as catalysts for the production of free radicals in biological systems. Many heavy metals like $\mathrm{Fe}, \mathrm{Cu}, \mathrm{Cd}, \mathrm{Cr}, \mathrm{Zn}$, etc. have been shown to cause oxidative damage in various higher plants (Reeves, 2003). The availability of heavy metals to plants and, thus, their toxicity depends on complex rhizospheric reactions involving not only exchange processes between soil and plants but also microbial activities (Singh and Ghosh, 2003).

\section{Antioxidative Defences of Plant against Heavy Metals}

It is evidence that exposure of plants to excess concentrations of redox active heavy metals such as Fe and $\mathrm{Cu}$ results in oxidative injury. The ability of plants to increase antioxidative protection to combat negative consequences of heavy metal stress appears to be limited since many studies showed that exposure to elevated concentrations of redox reactive metals resulted in decreased and not in increased activities of anti-oxidative enzymes (Weckx and Clijster, 1996). Exposure to heavy metals also provoked pronounced responses of antioxidative systems, but the direction of the response was dependent on the plant species and tissue analyzed, the metal used for the treatment and the intensity of the stress. However, some common reaction patterns can be found (Zenk, 1996).

In most cases, exposure to heavy metals initially resulted in a severe depletion of GSH. This is a common response to $\mathrm{Cd}$ caused by an increased consumption of glutathione for phytochelatin production. The significance of phytochelatin for protection from heavy metals has frequency been reviewed. For $\mathrm{Cd}$, the formation of Cd-thiolate (Cd-S) complexes in phytochelatins has been shown by previous workers. 
The chelated metals are transported to the tonoplast, taken up to active transport systems, and deposited in the vacuole. This mechanism contributes to the protection from heavy metal toxicity in several plant species and in some fungi as well. From the above results it is evident that the heavy metals Chromium affects significantly the biochemical factors, vitamins and mineral factors and antioxidant enzymes in both the plants. Among other species of plants the antioxidant property of Solanum nigrum is found to be higher than other plants.

\section{CONCLUSION}

In the present work the plants Solanum nigrum was exposed to the Chromium metal contaminated soils and the biochemical factors, vitamins and mineral factors and antioxidant factors were tested. The toxicity of the Chromium metal Solanum nigrum plant was investigated and the results were tabulated. From the above results it is evident that the heavy metal Chromium affects significantly the biochemical factors, vitamins and minerals factors and antioxidant enzymes in both the plant Solanum nigrum. According to review literature plants the overall antioxidant property of Solanum nigrum is found to be comparatively higher than other plant.

\section{REFERENCES}

Angelone M. and Bini C., 1992. Trace elements concentrations in soils and plants of Western Europe. In: Adriano DC, ed. Biogeochemistry of traces metals. Boca Raton, FL: Lewis Publishers, pp. 19-60.

Bergmann L. and Rennenberg H., 1993. Glutathione metabolism in plants. In: DeKok LJ, Stulen I, Rennenberg H, Brunold C, Rauser W, eds. Sulphur nutrition and assimilation in higher plants. The Hague: SPB Academic Publishing, pp. 109-124.

Berti W.R. and Cunningham S.D., 2000. In Phytoremediation of Toxic Metals: Using Plants to Clean Up the Environment. (ed.Raskin, I.) Wiley-Interscience, John Wiley and Sons, Inc. New York, pp. 71-88.

Blaylock M.J. and Huang J.W., 2000. Phytoextraction of metals. In: Raskin, I., Ensley, B.D. (Eds.) Phytoremediation of Toxic Metals: Using Plants to Clean up the Environment.- John Wiley and Sons, New York, pp. 53-70.
Blois M.S., 1958. Antioxidant determinationby the use of a stable free redical. Nature, 181: 1199-1200.

Chaoui A., Mazhoudi S., Chorbal M.H. and El Ferjani E., 1997. Cadmium and Zinc induction of lipid peroxidation and effects on antioxidant enzyme activities in bean (Phaseolus vulgaris L.). Plant Science, 127: 139-147.

Clemens S., Palmgren M.G. and Kramer U., 2002. A long way ahead: understanding and engineering plant metal accumulation. Trends in Plant Science, 7: 309-315.

Cobbett C.S., 2000. Phytochelatins and their role in Heavy metal Detxification. Plant Physiology, 123: $825-832$.

Gerard E., Echevarria G., Sterckeman T. and Morel J.L.P., 2000. Availability of $\mathrm{Cd}$ to three plant species varying in accumulation pattern. J. Environ. Qual., 29: 1117-1123.

Godbold D.L. and Hittermann A., 1985. Effect of zinc, cadmium and mercury on root enlogation of Picea abies (Karst.) seedlings, Environmental Pollution, 38: 375-381.

Kramer U. and Chardonnens A.N., 2001. The use of transgenic plants in the bioremediation of soils contaminated with trace elements. Applied Microbiology and Biotechnology, 55(6): 661672.

Koppolua L., Agblover F.A. and Clements L.D., 2003. Pyrolysis as a technique for separating heavy metals from hyperaccumulators. Part II: Labscale pyrolysis of synthetic hyperaccumulator biomass. Biomass and Bioenergy, 25: 651-663.

Lowry O.H., Rosebrough N.J., Farr A.L. and Randall R.J., 1951. "Protein measurement with the Folin phenol reagent”. J. Biol. Chem., 193(1): 265-75.

Mehra R.K. and Tripathi R.D., 1999. Phytochelatins and metal tolerance. In: Agarwal SB, Agarwal M, eds. Environmental pollution and plant responses. Boca Raton, FL: CRC Press, Lewis Publisher, pp. 367-382.

Rao K.V.M. and Sresty T.V.S., 2000. Antioxidative parameters in the seedlings of pigenonpea (Cajanus cajan (L). Millspaugh) in response to Zn and Ni stresses. Plant Science, 157: 113-129. 
Reeves R.D., 2003. Tropical hyperaccumulators of metals and their potential for phytoextraction. Plant and Soil, 249: 57-65.

Singh S.P. and Ghosh M., 2003. A Comparative study on effect of cadmium, chromium and lead on seed germination of weed and accumulator plant species.- Indian Journal of Environment Protection, 23(5): 513-518.
Weckx J.E.J. and Clijster H.M.M., 1996. Oxidative damage and defense mechanisms in primary leaves of Phaseolus vulgaris as a result of root assimilation of toxic amounts of copper. Physiologia Plantarum, 96: 506-512.

Zenk M.H., 1996. Heavy metal detoxification in higher plants a review. Gene, 179: 21-30. 